\title{
PENGEMBANGAN PEMASARAN DARING PRODUK DODOL NANGKA PADA UD. WARNA SARI DI DESA SURANADI KECAMATAN NARMADA KABUPATEN LOMBOK BARAT
}

\author{
Oleh : \\ I Gusti Agung Didit Eka Permadi \\ Universitas Mahasaraswati Denpasar \\ Ni Nyoman Harnika \\ IAHN Gde Pudja Mataram \\ Email korespondensi: diditekapermadi@unmas.ac.id
}

\begin{abstract}
ABSTRAK
Penyuluhan ini bertujuan supaya pihak manajemen UD. Warna Sari mengetahui bahwa pengembangan pemasaran daring atau e-marketing untuk produk dodol nangkanya selama masa pandemi COVID 19 sangat penting untuk dilaksanakan supaya eksistensi perusahaannya tetap terjaga. Materi penyuluhan disajikan menggunakan alat bantu LCD Projector dan slide powerpoint. Materi penyuluhan mencakup strategi pengembangan pemasaran daring atau e-marketing untuk produk dodol nangka selama masa pandemi COVID 19 dan pemanfaatan market place seperti facebook, instagram, bukalapak, tokopedia, dan whatsapp messenger yang menjadi media sosial sekaligus market place yang potensial bagi UD. Warna Sari. Kesimpulan yang dapat diperoleh dari kegiatan penyuluhan ini adalah aplikasi e-marketing memberikan peluang besar bagi pemasar, dalam hal ini pemasar adalah UD. Warna Sari sendiri untuk menekan biaya dan meningkatkan kepuasan pelanggan melalui layanan yang lebih cepat dan interaksi pemasaran yang lebih interaktif, real-time, dan efisien.

Kata kunci : Penyuluhan, e-marketing, pemasar, real-time, efisien.
\end{abstract}

ABSTRACT

This counseling is intended so that the management of UD. Warna Sari knows that the development of online marketing or e-marketing for their jackfruit dodol products during the COVID-19 pandemic is very important to carry out so that the company's existence is maintained. Material extension is presented using the tool auxiliary LCD Projector and powerpoint slides. The counseling materials include strategies for developing online marketing or e-marketing for jackfruit dodol products during the COVID-19 pandemic and the use of market places such as Facebook, Instagram, Bukalapak, Tokopedia, and WhatsApp Messenger which are social media as well as potential market places for UD. Warna Sari. The conclusion that can be derived from the activities of extension of this is the application of e-marketing provides an opportunity great for marketers, in terms of these marketers is UD. Warna Sari itself to suppress the cost and increase the satisfaction of customers through a service that is more rapid and the interaction of marketing that is more interactive, real-time, and efficiently.

Words key : Counseling, e-marketing, marketers, real-time, efficient. 


\section{PENDAHULUAN}

Desa Suranadi merupakan salah satu desa yang terletak di Kecamatan Narmada, Kabupataen Lombok Barat, Provinsi Nusa Tenggara Barat. Wilayah Desa Suranadi bersebelahan dengan Desa Sesaot bagian barat, Desa Narmada bagian timur, Desa Selat bagian utara, dan Desa Dasan Tereng bagian selatan.

Desa Suranadi memiliki delapan lingkungan dengan luas wilayah 9,54 km. Lingkungan yang terdapat di Desa Suranadi, meliputi Suranadi Barat, Suranadi Selatan, Eat Kendel, Kuang Mayung, Pemunut, Kalimanting, Orong Sedalem, dan Suranadi Utara. Desa Suranadi, Kecamatan Narmada, Kabupaten Lombok Barat memiliki ketinggian \pm 50 meter dari permukaan laut terletak pada $08^{\circ}, 33-08^{\circ}, 38^{\circ}$ Lintang Selatan dan $116^{\circ} 04^{\prime}-116^{\circ} 10^{\prime}$ Bujur Timur, suhu udara di Lombok Barat berkisar antara $20,4^{\circ} \mathrm{C}$ sampai dengan $32,10^{\circ} \mathrm{C}$ (BPS, 2019).

Wilayah Desa Suranadi memiliki jumlah penduduk sebanyak 6.238 jiwa. Sebagian besar penduduknya bekerja di sektor pertanian, sehingga peningkatan pembangunan di sektor ini akan dapat meningkatkan tarap hidup masyarakat di Desa Suranadi menjadi lebih baik. Perkebunan yang ada di Desa Suranadi umumnya menanam tanaman seperti nangka, manggis, durian, kelapa, kopi, kakao (coklat), jambu mete, dan rambutan, tetapi mayoritas masyarakat banyak yang memamfaatkan lahan mereka dengan menanam tanaman buah-buahan.

UD. Warna Sari didirikan pada tahun 2005. Perusahaan ini merupakan perusahan skala rumah tangga yang memproduksi dodol nangka, dodol durian dodol nanas, dodol sirsak, kripik ubi, dan kripik pisang. Sebelum memulai usaha ini awalnya hanya mengolah kripik ubi, dodol nangka, dan dijual di rumah pribadi pemiliknya dan karena lokasinya di Desa Suranadi sehingga mudah dijangkau oleh konsumen. Pada tahun 2011 usaha ini mulai dijalankan dengan produk olahan berupa dodol nangka, dodol durian, dodol sirsak, kripik ubi, dan lainnya dengan berbagai variasi rasa tertentu. Selanjutnya, pada tahun 2012 perusahaan ini mendapatkan sertifikasi dari Departemen Kesehatan sebagai produk yang aman dikonsumsi. Selain itu, produk di UD. Warna Sari juga telah memperoleh Identitas Halal dari Majelis Ulama Indonesia (MUI). Dengan adanya izin dan sertifikasi tersebut maka produk di UD. Warna Sari dapat dengan mudah dipasarkan. Seiring berjalannya waktu perusahaan ini secara terus-menerus mengembangkan produknya, baik dari segi diversifikasi produk maupun variasi kemasan guna memperluas pemasaran. Pemilik usaha sekaligus pimpinan di UD. Warna Sari sering mengikuti kegiatan pelatihan yang diadakan oleh Departemen Kesehatan (Depkes) untuk mengetahui tata cara pengembangan usaha, dengan harapan pengembangan produk secara bervariatif bertujuan memperluas jaringan bisnis pada waktu yang akan datang.

Pandemi COVID 19 telah melumpuhkan banyak sektor usaha, tidak terkecuali sektor UMKM (Usaha Mikro Kecil Menengah). UD. Warna Sari sebagai salah satu unit UMKM yang berada di Desa Suranadi Kecamatan Narmada Kabupaten Lombok Barat ikut terkena dampaknya. Selama masa pandemi, Pimpinan UD. Warna Sari mengambil kebijakan untuk tetap mempertahankan eksistensi usahanya. Strategi $e$-marketing yakni pengembangan pemasaran daring produk dodol nangka harus diterapkan. Market place seperti facebook, instagram, bukalapak, tokopedia, dan whatsapp messenger menjadi media sosial sekaligus market place yang potensial. UD. Warna Sari diharapkan dapat menerapkan strategi 
pengembangan pemasaran daring produk dodol nangkanya supaya dapat bertahan dalam menghadapi masa pandemi ini.

Permasalahan dalam kegiatan penyuluhan ini adalah kurangnya pemahaman pihak manajemen UD. Warna Sari dalam pengembangan pemasaran daring atau e-marketing untuk produk dodol nangkanya selama masa pandemi COVID 19. Penyuluhan ini bertujuan supaya pihak manajemen UD. Warna Sari mengetahui bahwa pengembangan pemasaran daring atau e-marketing untuk produk dodol nangkanya selama masa pandemi COVID 19 sangat penting untuk dilaksanakan supaya eksistensi perusahaannya tetap terjaga. Penyuluhan ini mempunyai sasaran kepada pihak manajemen UD. Warna Sari yang selanjutnya diharapkan mampu menerapkan strategi pengembangan pemasaran daring atau $e$ marketing untuk produk dodol nangkanya selama masa pandemi COVID 19. Manfaat dari penyuluhan ini diharapkan agar : (1). Pihak manajemen UD. Warna Sari dapat mengetahui strategi pengembangan pemasaran daring atau e-marketing untuk produk dodol nangkanya selama masa pandemi COVID 19 dan (2). Pihak manajemen UD. Warna Sari dapat mengetahui market place seperti facebook, instagram, bukalapak, tokopedia, dan whatsapp messenger yang menjadi media sosial sekaligus market place yang potensial.

\section{METODE PELAKSANAAN KEGIATAN PENYULUHAN}

Sesuai dengan hasil observasi lapangan, maka lokasi penyuluhan ditetapkan di UD. Warna Sari yang terletak di Desa Suranadi Kecamatan Narmada Kabupaten Lombok Barat dengan pertimbangan bahwa UD. Warna Sari sangat potensial untuk mengembangkan usahanya di masa yang akan datang. Penyuluhan ini dilaksanakan pada Senin, 11 Mei 2020 pukul 08.00 Wita sampai dengan pukul 11.00 Wita. Penyuluhan ini dilaksanakan atas pembiayaan dari Unit LPPM Universitas Mahasaraswati Denpasar PSDKU Mataram, melalui anggaran tahun akademik semester genap 2019/2020, sebesar Rp 2.000.000,-. Peserta penyuluhan terdiri dari pemilik sekaligus pimpinan dan seluruh karyawan UD. Warna Sari. Adapun jumlah pesertanya adalah 5 (lima) orang. Materi penyuluhan disajikan menggunakan alat bantu LCD Projector dan slide powerpoint. Materi penyuluhan mencakup strategi pengembangan pemasaran daring atau $e$-marketing untuk produk dodol nangka selama masa pandemi COVID 19 dan pemanfaatan market place seperti facebook, instagram, bukalapak, tokopedia, dan whatsapp messenger yang menjadi media sosial sekaligus market place yang potensial bagi UD. Warna Sari. Pimpinan UD. Warna Sari selaku pihak manajemen menjadi peserta yang difokuskan untuk memperoleh materi penyuluhan ini sedangkan para karyawan yang lain hanya mendengarkan. Teknik penyampaian materi penyuluhan ini adalah dengan menggunakan teknik ceramah, yang kemudian disusul dengan acara diskusi atau tanya jawab. 


\section{HASIL DAN PEMBAHASAN}

Berdasarkan hasil pengamatan tim penyuluh seperti yang dikemukakan pada uraian di atas, maka dapat dikemukakan faktor penghambat dan pendorong dari usaha penyuluhan ini. Di samping itu disajikan pula hasil evaluasi yang dilaksanakan oleh tim penyuluh.

\section{A. Faktor Penghambat}

Dari hasil pengamatan tim, hambatan yang kiranya perlu diinformasikan melalui laporan ini adalah adanya keterbatasan ruangan yang dimiliki oleh UD. Warna Sari untuk mendukung pelaksanaan penyuluhan. Ruangan yang dimaksudkan oleh tim penyuluh adalah ruangan yang memiliki daya tampung yang dapat digunakan untuk menyelenggarakan suatu pertemuan, tetapi setelah dibicarakan dengan pimpinan UD. Warna Sari maka ruangan yang cukup besar untuk dapat digunakan menyelenggarakan penyuluhan adalah ruangan yang terletak di samping toko oleh-oleh UD. Warna Sari dan ruangan ini biasa digunakan oleh karyawan untuk beristirahat dan makan siang bersama.

\section{B. Faktor Pendorong}

Dilihat dari jalannya penyuluhan ini, peserta penyuluhan tampaknya antusias mengikuti seluruh kegiatan dari awal hingga akhir. Adanya rasa saling membutuhkan antara tim dengan peserta yang mana dirasa mampu menumbuhkan jalinan kerja sama, baik pada saat berlangsungnya penyuluhan ini maupun di masa yang akan datang.

\section{Evaluasi}

Dilihat dari hasil pengamatan tim, maka materi penyuluhan ini ada relevansinya dengan masalah yang sedang dihadapi oleh UD. Warna Sari dan dapat mengenai sasaran. Hal ini dapat terlihat dari pertanyaan-pertanyaan yang muncul dan dilontarkan oleh peserta kepada tim penyuluh.

Setelah diadakan ceramah, kemudian peserta mengajukan beberapa pertanyaan yang dapat tim penyuluh sajikan sebagai berikut :

\section{Pak Mesir Suryadi}

Apa keuntungan yang diperoleh UD. Warna Sari nantinya jika menggunakan aplikasi e-marketing ini, khususnya mengenai strategi pengembangan pemasaran daring produk dodol nangka selama menghadapi masa pandemi COVID 19 ini ?

\section{Jawaban :}

Begini Pak Mesir Suryadi, aplikasi e-marketing memberikan peluang besar bagi pemasar, dalam hal ini pemasar adalah UD. Warna Sari sendiri untuk menekan biaya dan meningkatkan kepuasan pelanggan melalui layanan yang lebih cepat dan interaksi pemasaran yang lebih interaktif, real-time, dan efisien (Tjiptono dan Diana, 2016 : 313). UD. Warna Sari dapat memposisikan diri selama menghadapi masa pandemi COVID 19 dengan memberikan nilai lebih kepada pasar sasaran, baik dengan menawarkan harga yang lebih murah daripada harga yang ditawarkan pesaing maupun dengan memberikan keunggulan untuk mendukung harga yang lebih mahal maka UD. Warna Sari akan mendapatkan manfaat kompetitif (Machfoedz, 2005 : 77). Aktivitas e-marketing akan memberikan publisitas. Publisitas merupakan bagian dari fungsi yang lebih luas, disebut hubungan masyarakat, dan meliputi usaha-usaha untuk menciptakan dan mempertahankan hubungan yang menguntungkan antara UD. Warna Sari dengan masyarakat, termasuk pemilik UD. Warna Sari, karyawan, lembaga pemerintah, penyalur, 
serikat buruh, di samping juga calon pembeli. Komunikasi dengan masyarakat luas melalui hubungan masyarakat ini dapat mempengaruhi kesan terhadap UD. Warna Sari maupun terhadap produk dodol nangka yang ditawarkan (Swastha dan Irawan, $2008: 352$ ).

\section{Bu Anti}

Bukalapak adalah salah satu situs jual beli online yang mudah dan terpercaya. Bagaimanakah cara membuat akun sebagai penjual/pelapak di bukalapak ?

\section{Jawaban :}

Begini $\mathrm{Bu}$ Anti, untuk membuat akun pelapak/penjual di situs bukalapak.com caranya seperti ini pertama, masuk ke situs bukalapak.com selanjutnya mengisi data-data sebagai pelapak/penjual, kedua, membuat akun toko/lapak online, dan tahap ketiga sekaligus sebagai tahap terakhir adalah mengunggah foto produk yang akan dijual yaitu dodol nangka. Ketika UD. Warna Sari memutuskan untuk menjual produk dodol nangkanya secara online melalui situs jual beli online seperti bukalapak.com maka diperlukan kesan (image) audience. Salah satu langkah terpenting di dalam analisa audience ialah penilaian terhadap gambaran yang dimiliki audience mengenai perusahaan, produk perusahaan, dan saingan perusahaan untuk menentukan tujuan komunikasi. Salah satu teknik untuk mengukur kesan audience ialah yang dikenal dengan nama "semantic differential" (Radiosunu, 2001 : 197). Kesan didasarkan atas beberapa faktor yaitu evaluasi (kesan baik buruk), potensi (sifat kuat lemah), dan aktivitas (sifat aktif pasif). Untuk membuat suatu profil kesan terhadap perusahaan dan saingan, dalam hal ketiga faktor tersebut. Kemudian penilaian para pembeli dirata-ratakan. Penilaian seperti demikian dalam aplikasi bukalapak.com dapat dilakukan ketika pembeli sudah menerima barang yang dibeli sesuai dengan alamat tujuan pengiriman. Pada menu transaksi, pembeli dapat memilih submenu konfirmasi penerimaan barang yang telah dikirimkan oleh pelapak. Selanjutnya, pembeli mengisi respon kepuasan, baik terhadap barang yang dibeli maupun pelayanan pelapak. Tahap terakhir adalah pembeli memberikan ulasan terhadap barang yang telah dibeli apakah sudah sesuai dengan pesanan ataukah terkait dengan harga barang itu sendiri, baik itu harganya terjangkau atau terlalu mahal. Ya silahkan saja diulas oleh pembeli dan juga berikan peringkat (rating) berupa bintang untuk kualitas dan kinerja dari barang yang sudah dibeli.

\section{Pak M. Herman}

Jika ada pelanggan yang memesan produk dodol nangka melalui aplikasi whatsapp messenger dan metode pembayarannya menggunakan cash on delivery maka apakah ini masih tergolong sebagai e-marketing ?

\section{Jawaban :}

Begini Pak M. Herman, dalam aktivitas e-marketing banyak dikenal metode pembayaran yaitu menggunakan transfer rekening bank, saldo doku (dompet virtual), pembayaran via gerai seperti indomaret atau alfamart, dan cash on delivery. Jadi walaupun proses pemesanannya melalui media sosial seperti whatsapp messenger dan si pelanggan membayarnya langsung ketika barang diterima di alamat tujuan (cash on delivery) maka aktivitas ini tetap disebut sebagai e-marketing. Pada umumnya suatu perusahaan tidak menentukan harga jual produknya secara tunggal dan tetap, akan tetapi sering diubah-ubah disesuaikan dengan keadaan pasar. Harga jual yang ditetapkan sebaiknya selalu diubah mengikuti berbagai faktor antara lain : siklus kehidupan produknya, biaya maupun 
tingkat permintaan dan perubahan selera konsumen. Dalam hal perusahaan akan memasarkan produk baru dapat dipergunakan salah satu dari strategi harga, yaitu : (a) penetapan harga setingi-tingginya (market-skimming pricing) dan (b) penetapan harga serendah-rendahnya (market-penetration pricing). Apabila perusahaan ingin mengembangkan produk baru, maka persoalan yang paling pokok adalah penentuan posisi produk. Dalam penentuan posisi produk ini, ada beberapa pilihan strategi harga dan kualitas produk yang perlu diambil (Gitosudarmo, 2008 : 274). Banyak ekonom mengasumsikan bahwa konsumen adalah "penerima harga" dan menerima harga pada "nilai muka" atau sesuai yang diberikan. Pemasar menyadari bahwa konsumen sering memproses informasi harga secara aktif, menerjemahkan harga berdasarkan pengetahuan mereka dari pengalaman pembelian sebelumnya, komunikasi formal (iklan, telepon penjualan, dan brosur), komunikasi informal (teman, kolega, atau anggota keluarga) titik pembelian atau sumber daya online, atau faktor lainnya (Kotler dan Keller, 2009 : 72).

\section{SIMPULAN DAN SARAN Simpulan}

Berdasarkan hasil dan pembahasan yang telah dipaparkan maka kesimpulan yang dapat diperoleh dari kegiatan penyuluhan ini adalah sebagai berikut :

a. Aplikasi e-marketing memberikan peluang besar bagi pemasar, dalam hal ini pemasar adalah UD. Warna Sari sendiri untuk menekan biaya dan meningkatkan kepuasan pelanggan melalui layanan yang lebih cepat dan interaksi pemasaran yang lebih interaktif, real-time, dan efisien.

b. Ketika UD. Warna Sari memutuskan untuk menjual produk dodol nangkanya secara online melalui situs jual beli online seperti bukalapak.com maka diperlukan kesan (image) audience.

c. Dalam aktivitas e-marketing banyak dikenal metode pembayaran yaitu menggunakan transfer rekening bank, saldo doku (dompet virtual), pembayaran via gerai seperti indomaret atau alfamart, dan cash on delivery.

\section{Saran}

Berdasarkan kesimpulan yang telah dipaparkan maka dapat diberikan rekomendasi sebagai berikut :

Aplikasi e-marketing yang akan dikembangkan oleh UD. Warna Sari selama masa pandemi COVID 19 haruslah mengedepankan sikap saling percaya. Kepercayaan merupakan kunci sukses dalam melaksanakan aktivitas e-marketing, walaupun baru menggunakan aplikasi whatsapp messenger dan metode pembayarannya dengan cash on delivery tetapi UD. Warna Sari tetap mempertahankan eksistensi bisnisnya dengan tidak kehilangan kepercayaan dari para pelanggannya. Market place seperti bukalapak.com merupakan situs jual beli online yang mudah dan terpercaya yang akan sangat membantu UD. Warna Sari untuk menjual produk dodol nangkanya secara nasional dan akan memperoleh pelanggan baru yang tersebar di seluruh Indonesia. 


\section{DAFTAR PUSTAKA}

Kotler, P. dan Kevin Lane Keller. 2009. Manajemen Pemasaran. Edisi 13. Jilid 2. Jakarta : Erlangga.

Gitosudarmo, H. I. 2008. Manajemen Pemasaran. Edisi Kedua. Yogyakarta : BPFE UGM.

Machfoedz, M. 2005. Pengantar Pemasaran Modern. Yogyakarta : UPP AMP YKPN.

Mubyarto. 1982. Pengantar Ekonomi Pertanian. Jakarta : LP3ES.

Radiosunu. 2001. Manajemen Pemasaran : Suatu Pendekatan Analisis. Yogyakarta : BPFE UGM.

Swastha Dh, B. dan Irawan. 2008. Manajemen Pemasaran Modern. Yogyakarta : Liberty.

Tjiptono, F. dan Anastasia Diana. 2016. Pemasaran : Esensi dan Aplikasi. Edisi I. Yogyakarta : ANDI. 